\title{
Analysis of Factors Affecting Self Care in Kusta Patients in Daha Husada Kediri Hospital
}

\author{
Hadi Santoso, Nurdina, \\ Nurwijayanti \\ Dhaha Husada Hospital Kediri, \\ Indonesia \\ Email: \\ hadisan@gmail.com
}

Received : March 12, 2019

Accepted : October 13, 2019

Published : November 26, 2019

\begin{abstract}
Leprosy is a disease that can lead to physical disability and psychological disorders in leprosy patients who can be significantly reduced by self care. Several factors that can affect self care in leprosy patients include the degree of disability, stigma, family support and self-acceptance. This study aims to analyze the factors that influence self care in leprosy patients at Daha Husada Kediri Hospital. The research design used in this study is analytic with a cross sectional approach. The number of samples in this study is 116 respondents who meet the inclusion criteria and are taken by the rendom sampling technique. The independent variable in this study is the degree of disability, stigma, family support and self-acceptance while the dependent variable is self care. Data analysis using Pearson Correlation and Beta Coefficient statistical tests The results showed that the majority of leprosy patients had a disability level of $1(62.9 \%)$, moderate stigma (58.6\%), high family support $(52.6 \%)$ and acceptance moderate self $(53.4 \%)$, The results of the Pearson correlation statistical test showed that family support $p 0,000$ Pearson correlation 0,483 and self-acceptance p 0,000 Pearson correlation 0,584 were meaningful and from the results of the regression coefficients the Beta Coefficient showed that selfacceptance was the most powerful factor with self care in leprosy patients at Daha Husada Kediri Hospital. Daha Husada Kediri Hospital is expected to be able to further improve health service efforts to change the negative stigma in the community by socializing leprosy.
\end{abstract}

Keywords : Stigma, Family Support, Self-Acceptance, Self Care, Leprosy Patients 


\section{INTRODUCTION}

Today, competition between hospitals is getting stronger, especially with the increasingly critical thinking of the people, so that the demands of the community for the quality of service are increasingly high, the services provided by the hospital must be truly quality and satisfying.

Leprosy is a contagious, chronic disease and is caused by obligate intracellular leprosy (Mycobacterium Leprae). Peripheral / peripheral nerves as first affinity, then skin, upper respiratory tract mucosa. limbs and eyes and cause injury, joint stiffness, even disability in leprosy patients (Kemenkes RI, 2012 in Dhelya Wydasmara 2018). Leprosy is one of the world's health problems and is one of the neglected tropical diseases in the world, According to WHO data the number of new cases found 210,758 cases $70 \%$ came from Southeast Asia 156,118 new cases, Indonesia ranks third in the world with 15,920 new cases with a level 2 disability rate still $6.6 \%$ of the target of $<5 \%$. East Java ranks first in Indonesia with the discovery of new patients in 2017 as many as 3,373 people (Dirjen P2P, Kemenkes RI, 2018). the number of outpatients in leprosy poly Daha Husada Kediri Hospital in June 2018 as many as 164 patients with level 2 disabilities were 29 patients (18\%) this number was higher than the target for leprosy elimination that the level 2 disability rate was less than 5\%.(RS, Kusta Kediri. (2018). Profil RS Kusta Kediri). With the still high level 2 disability one reason is the lack of self-care in line with Susanto (2013) Leprosy patients have problems in meeting basic needs and the ability of clients to carry out self-care. The inability of leprosy clients to fulfill basic needs and the ability of clients in self-care is a self care deficit that clients experience. The ability to fulfill basic needs in work relates to physical conditions and disability which results in leprosy clients being less productive in their work. Problems experienced by leprosy clients that cover all aspects of their lives require a good care from the family to encourage treatment. (Susanto, 2013). Leprosy patient in carrying out treatment generally relate to the condition of the wounds they have and the condition of the contracture or disability they experience. (WHO, 2000 in Susanto, 2013).

Self care agency can change at any time which is influenced by predisposing factors (predisposing factors) which consist of knowledge, attitudes, beliefs in education and work. The second is the enabling factor which consists of infrastructure and distance from health services. The third is the reinforcing factor in the form of family support roles and the existence of rules. (Nursalam, 2013). Self care agency can change at any time which is influenced by predisposing factors (predisposing factors) which consist of knowledge, attitudes, beliefs in education and work. The second is the enabling factor which consists of infrastructure and distance from health services. The third is the reinforcing factor in the form of family support roles and the existence of rules. (Nursalam, 2013). Physical problems of leprosy clients arise due to the condition of lesions on the client's skin that deteriorate until there is physical disability. (Susanto, 2013). This obstacle resulted in increased leprosy sufferers with physical limitations. So the impact of self care deficit on leprosy clients is disability.

The stigma and discrimination shown by the community towards leprosy patients has a negative impact. Stigma arises because of disability caused by leprosy and fear of people that muadah lepra is contagious and very dangerous (Soedjartami, 2009). Family support is very much needed by leprosy patients, because support from the family can improve the quality of humanity, stability of personality, behavior, and ability to relate very well (Friedman et al, 2010). the lack of family support results in patients withdrawing so that patients do not seek treatment and take good care of themselves.

Based on the above phenomena, researchers are interested in conducting research with the title "Analysis of Factors Affecting Self Care in Leprosy Patients in Daha Husada Kediri Hospital".

\section{MATERIALS AND METHODS}

This study uses analytical design with a Cross Sectional approach. The number of respondents in this study was 116 leprosy patients obtained by means of sampling. The research was conducted from August to September 2018. The instruments used in this study were the Stigma questionnaire, family support, self-acceptance and self care for the degree of disability in accordance with WHO and the Indonesian Ministry of Health.

Data analysis used in this study is Pearson Correlation analysis to determine the relationship of the degree of disability, stigma, family support and self-acceptance of self care in leprosy patients. while the Beta Coefficient analysis to determine the most influential factors for self care in leprosy patients at Daha Husada Kediri Hospital. 
RESULT

Distribution of Frequency Characteristics of Respondents in Daha Husada Kediri Hospital In August September 2018

\begin{tabular}{|c|c|c|c|}
\hline No & Characteristics & Frequnency & Percentage \\
\hline \multirow{2}{*}{ Sex } & a. Man & 51 & $43.90 \%$ \\
\hline & b. Women & 65 & $56.10 \%$ \\
\hline \multirow{5}{*}{ Age } & a. $<20$ Year & 0 & $0 \%$ \\
\hline & b. 21-30 Year & 9 & $7.7 \%$ \\
\hline & c. $31-40$ Year & 85 & $73.3 \%$ \\
\hline & d. 41-50 Year & 19 & $16.4 \%$ \\
\hline & e. $>50$ Year & 3 & $2.6 \%$ \\
\hline \multirow{5}{*}{$\begin{array}{l}\text { latest } \\
\text { education }\end{array}$} & a. no school & 0 & $0 \%$ \\
\hline & b. Elementary school & 60 & $51.7 \%$ \\
\hline & c. Junior high school & 34 & $29.37 \%$ \\
\hline & d. High school & 22 & $20 \%$ \\
\hline & e. College & 0 & 0 \\
\hline \multirow{5}{*}{ Work } & a. No Working & 63 & $54.30 \%$ \\
\hline & b. Private & 9 & $7.75 \%$ \\
\hline & c. The farmer & 38 & $32.75 \%$ \\
\hline & d. Entrepreneur & 6 & $5.2 \%$ \\
\hline & e. Goverrnent employees & 0 & 0 \\
\hline \multirow{2}{*}{ Status } & a. Merried & 103 & $88.8 \%$ \\
\hline & b. single & 13 & $11.2 \%$ \\
\hline \multirow{2}{*}{ Tipe } & a. $\quad$ Pausibasiler $(\mathrm{PB})$ & 27 & $23.3 \%$ \\
\hline & b. Multibasiler (MB) & 89 & $76.7 \%$ \\
\hline
\end{tabular}

Distribution of Respondents Based on the Degree of Disability in Daha Husada Kediri Hospital in August-September 2018

\begin{tabular}{rccc}
\hline Indicator & Category & Frequnency & Percentage \\
\hline \multirow{2}{*}{ Leprosy Disability } & 0 & 43 & $37.1 \%$ \\
& 1 & 73 & $62.9 \%$ \\
\hline Total & & 116 & $100 \%$ \\
\hline
\end{tabular}

Characteristics of Stigma Factors in leprosy patients at Daha Husada Kediri Hospital in August September 2018

\begin{tabular}{|c|c|c|}
\hline Stigma & Frequnency & Percentage \\
\hline High & 30 & $28.9 \%$ \\
\hline Medium & 68 & $58.6 \%$ \\
\hline low & 18 & $15.5 \%$ \\
\hline Total & 116 & $100 \%$ \\
\hline
\end{tabular}

Characteristics of Family Support Factors at Daha Husada Kediri Hospital in August-September 2018

\begin{tabular}{lcc}
\hline Family support & Frequnency & Percentage \\
\hline High & 61 & $52.6 \%$ \\
Medium & 33 & $28.4 \%$ \\
low & 22 & $19 \%$ \\
\hline Total & 116 & $100 \%$ \\
\hline
\end{tabular}


Characteristics of Factors Self-acceptance of leprosy patients at Daha Husada Kediri Hospital in August - September 2018

\begin{tabular}{lcc}
\hline Accepting yourself & Frequnency & Percentage \\
\hline High & 42 & $36,2 \%$ \\
Medium & 62 & $53,4 \%$ \\
low & 12 & $10,4 \%$ \\
\hline Total & 116 & $100 \%$ \\
\hline
\end{tabular}

Self Care Characteristics of leprosy patients at Daha Husada Kediri Hospital in August - September 2018

\begin{tabular}{lcc}
\hline Self Care & Frequnency & Percentage \\
\hline Good & 50 & $43.1 \%$ \\
Medium & 43 & $37.1 \%$ \\
Less & 23 & $19.8 \%$ \\
\hline Total & 116 & $100 \%$ \\
\hline
\end{tabular}

Special Data

Effect of Disability Degrees, Stigma, Family Support and Self Acceptance on Self Care

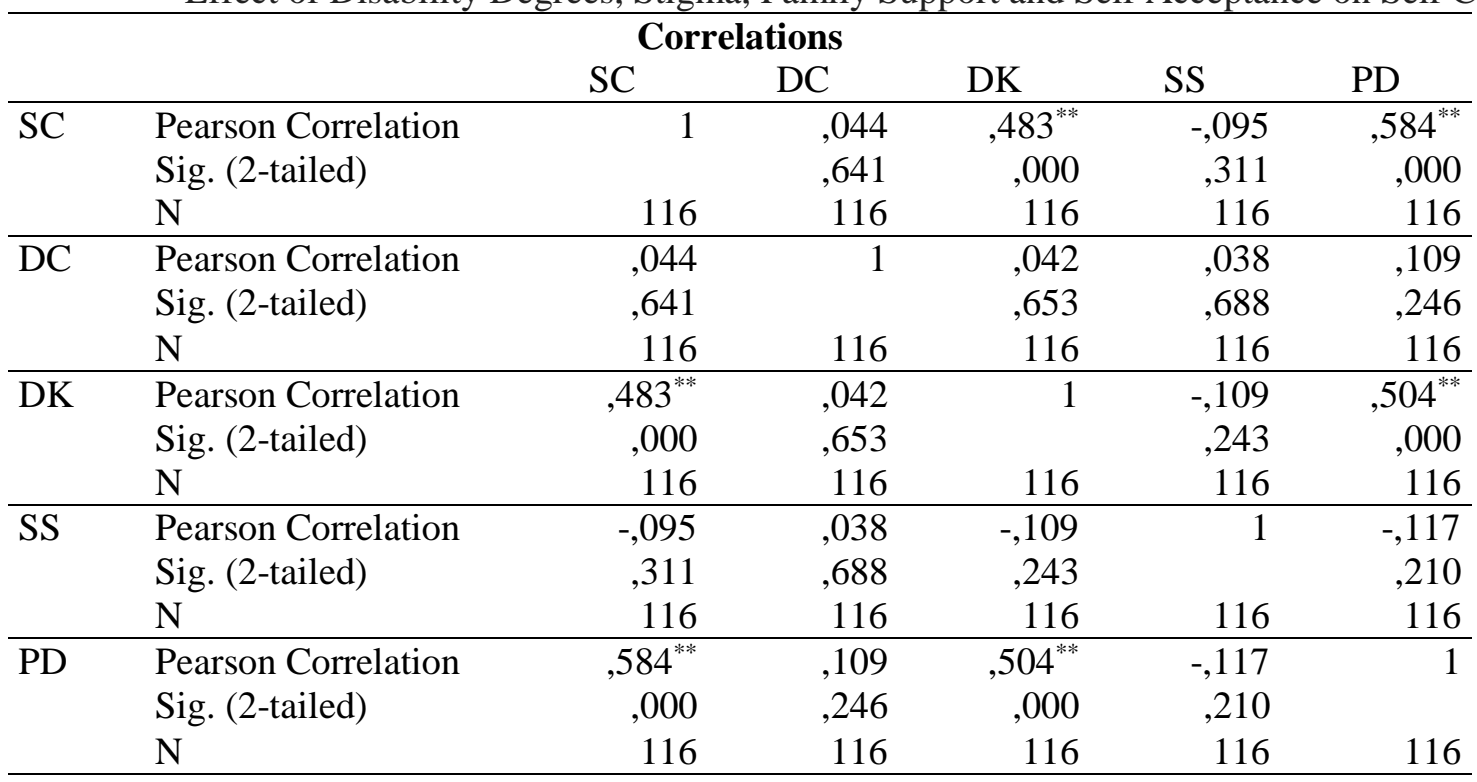

The degree of disability with self care with the results of $\mathrm{p} 0.641$ Pearson correlation 0.044 , social stigma with self care with results p 0.311 Pearson correlation -0.095 , family support with self care with results p 0,000 Pearson correlation 0.483 , self-acceptance with self care with results $\mathrm{p} 0.000$ Pearson correlation 0.584

\section{DISCUSSION}

Analysis of the degree of disability of leprosy with self care

Leprosy defects occur due to nerve function disorders in the eyes, hands or feet. Unfortunately, people who are handicapped by leprosy are "labeled" for life as "lepers" even though they have recovered from the disease. While in fact almost all defects can be prevented, Kemenkes RI (2012) dalam Dhelya Widasmara (2018).

Kemenkes RI (2014) dalam Dhelya Widasmara (2018) revealed that Multibacillary type of leprosy $(\mathrm{MB})$ is more likely for patients with disability compared to the Pausibasiler (PB) type is related to the finding of Acid Resistant Basil (BTA) in MB type, and nerve thickening accompanied by more than 1 function disorder whereas in PB type not found leprosy germs and thickening of the nerves accompanied by functional disorders only 1 nerve.

Self care is an ongoing contribution of adults to their existence, health, and well-being. Self care describes and explains the benefits of self-care in order to maintain life, health, and well-being. If done 
effectively, self-care efforts can contribute to the structural integrity of human function and development (Siokal, Patmawati, 2017).

The results of the study at Daha Husada Kediri Hospital showed that the majority of leprosy patients had a disability level of 73 people (62.9\%), the respondents had the most Multibacillary leprosy type (MB) 89 people (76.7\%). most leprosy patients have good self care, as many as 50 people $(43.1 \%)$, most of the respondents have the highest self care indicators, namely eye care indicators in the moderate category, namely as many as 70 people $(60.3 \%)$, hand care in the moderate category, as many as 52 people $(44.8 \%)$, foot care in the good category as many as 49 people $(42.2 \%)$.

The degree of disability in leprosy patients is not only determined by self care but is also caused by leprosy itself, especially in MB type leprosy patients. Disability in leprosy patients can actually be prevented by early discovery, early diagnosis, regular and accurate treatment with MDT and with good self care.

Self care for the eyes that are not good can cause disability in the eyes, including the eyes can not close (Lagoptalmous), Self care on the hands that are not good can cause dryness, cracks and cracked skin that does not feel injured even fingers until crooked, while self care on a bad foot can cause dryness, cracks and cracked skin that doesn't feel sore, the legs become perfect.

Good self care will prevent disability in leprosy patients even if the patient has a disability with self care that has good disability in leprosy patients does not get worse.

\section{Stigma Analysis with Self Care}

Stigma is a sign or characteristic that indicates the owner brings something bad and therefore is considered lower than normal people (Phelan.J.C., Link, B.G., \& Dovidio, J.F. 2008)

Stigma indicators are aimed at individuals or groups so that individuals or groups will feel uncomfortable with the process of social interaction that is done so that it has an impact on the limited social relationships of individuals with others.

Stigma received by individuals continuously can cause depression, reluctance to carry out self-care activities (Phelan.JC, Link, BG, \& Dovidio, JF 2008 in Brown \& Scheid, 2010). Leprosy patients are generally still feared and ostracized by society. . Unfair treatment of leprosy patients will cause social problems that can affect the interaction of leprosy patients in the community (Lucka, 2010; Sutrisno, 2014).

Sulidah (2016) argues that there is a meaningful relationship between knowledge and attitudes of the community regarding leprosy towards discrimination in leprosy patients. . Negative stigma about leprosy gives an indication of the low level of knowledge of the community which has implications for the emergence of negative attitudes which are manifested in the discontinuation of leprosy patients. The results of the study at Daha Husada Hospital showed that most leprosy patients had moderate social stigma of 68 people (58.6\%), the most indicators of alienation stigma were low category 73 people (62.9\%), low category stereotyping indicators79 people ( 68\%), the indicator of low discrimination stigma was 75 people $(64.7 \%)$ and the stigma indicator for social withdrawal was 73 people $(62.9 \%)$. Leprosy patients at Daha Husada Kediri Hospital do not experience alienation because their families and communities have understood or understood leprosy from brochures mass media, socialization of leprosy and the advancement of technology that makes people easily access knowledge to make families or communities able to understand leprosy so as not to alienate leprosy patients . With the family and the community knowing and understanding about leprosy, not giving a negative assessment and being able to accept leprosy patients, this makes the leprosy patient still able to contribute to society and assume that he does not fail in life, with no stigma (Lepropobia) in leprosy patients by the community, making patients feel valued is needed so that leprosy patients will perform regular treatment and self care so there is no disability in patients.

\section{Analysis of Family Support with Self Care}

Family support is an attitude, an act of family acceptance of family members, in the form of informational support, assessment support, instrumental support and emotional support. So family support is a form of interpersonal relations that includes attitudes, actions and acceptance of family members, so that family members feel someone is paying attention (Friedman, 2010)

The results of the study at Daha Husada Kediri Hospital were mostly respondents who had high family support as many as 61 people (52.6\%). i.e. the medium Emotional support indicator amounted to 68 
people $(58.6 \%)$ most of the respondents had real moderate support ie 57 people $(49.1 \%)$ and most of the respondents had high information support which was 59 people (50.8\%) From the results of the analysis show that $\mathrm{p} 0,000$ Pearson Correlation 0.483 there is a relationship between family support and self care, namely the higher family support, the better self care of leprosy patients as well as vice versa that the lower family support, the less self care of leprosy patients. The success of patients in doing self care is inseparable from family support both emotional support by assisting patients in care, giving praise and understanding that the pain experienced by patients is a disaster. The family also provides real support in the care carried out by leprosy patients.

Information support is useful in providing information to leprosy patients about the treatment of leprosy, treatment schedules and advice on treating leprosy so as not to get worse. The high level of information support in leprosy patients at Daha Husada Kediri Hospital can be caused by several factors including information received by the family regarding leprosy is good enough, the family is skilled in delivering information to leprosy patients and is also supported by leprosy patients who receive information from their families and cooperate well. Informational support was applied by the family of leprosy patients at Daha Husada Kediri Hospital by assisting leprosy patients to seek treatment and obtain explanations or information and health workers related to leprosy and patient care at home. Support from this family is very helpful and very meaningful for leprosy patients so that patients feel needed and needed in the family so that patients need to do good self care so that there is no disability in leprosy patients.

\section{Analysis of Self Acceptance with Self Care}

Self-acceptance is the ability of an individual to acknowledge and accept his condition as he is in accordance with reality and experience with the background of life and the immediate environment. Individual recognition of limitations in him will not be followed by feelings of shame or guilt so that individuals are able to accept the situation as it is (Chaplin, 2008; Riyanto in Hartati, 2013)

In line with this study (Soedarjatmi et al. 2009), leprosy patients sought to avoid negative responses in the community by continuing to work, not seek treatment, limit themselves, close themselves and not care about their environment as if they had no leprosy.

The above reflects that leprosy patients still do not accept the condition of the disease. self-acceptance of leprosy patients is influenced by several factors including marital status and age (Kumianingtyas, 2009). Judging from the status of marriage, an individual at the age of early adulthood will have different self-acceptance. This is reinforced by the opinion of Diener, Judge \& Watanabe in Kumianingtyas (2009) that marital status contributes to individual life satisfaction.

The results of the study at Daha Husada Kediri Hospital found that most respondents had moderate selfacceptance as many as 62 people $(53.4 \%)$. Most respondents had the highest self-acceptance indicators, namely indicators of physical acceptance in the moderate category, namely 63 people $(54.3 \%)$, indicators self-protection in the High category as many as 54 people (47\%), self-capacity indicators in the medium category as many as 52 people $(44.8 \%)$, and from the results of the analysis showed that the higher the self-acceptance of leprosy patients the better the patient's self care Likewise, leprosy also vice versa that the lower the self-acceptance of leprosy patients, the less self care of leprosy patients self care will be carried out happily by leprosy patients at Daha Husada Hospital because the patient is willing to accept his body condition and recognize his strength and the patient thinks that he is physically penetrating so that the leprosy patient will try to maintain his physical condition so that disability is not treated. self care well.

The results showed that self-acceptance of self-protection indicators in this high category was because patients felt worried about negative attitudes, negative prejudices from the community and unreasonable questions about leprosy all of which could be reduced by socialization of leprosy to the community and good self care so that leprosy patients with no defects caused by leprosy germs with no visible defects make a negative view of leprosy patients occur, with leprosy patients can think positively about the life that leprosy is not a barrier to interact with the community and also not as a barrier to achieve the dreams you want to achieve so that the patient will think that taking care of himself (self care) it is important and is a need that they must do every day with pleasure.

Good self-acceptance in leprosy patients at Daha Husada Hospital is also influenced by the level of maturity or maturity of patients and the status of research results 85 people $(73.7 \%)$ aged $31-40$ years, while patients who were married 103 people $(88,8 \%)$. Maturity or emotional maturity of a person to be able to respond positively to obstacles, problems and changes that occur related to the life process. The 
more mature a person is, the more objective he will be in making decisions and judging everything that happens to him with a positive self-acceptance as well as married patients will have a higher level of life satisfaction compared to unmarried individuals because marriage for most people is the peak of life satisfaction and the patient will feel that he is very needed by his companion so that the patient feels that his companion also has the right to be happy which makes the patient maintain his body so that there is no disability in him by doing good self care that can improve self-acceptance.

Good self-acceptance contributes to leprosy patients to achieve happiness which is characterized by patients accepting themselves as they are, thinking positively, having confidence in their potential and free from excessive worry

\section{The factors that most affected self care of leprosy patients at the Daha Husada Kediri}

Based on the results of the research analysis the most powerful factor affecting self care in leprosy patients at Daha Husada Kediri Hospital is family support with the results of p 0,000 Pearson correlation 0.483 so that family support has a strong relationship with self care and self-acceptance with p 0,000 Pearson correlation 0.584 so self-acceptance there is a strong relationship with self care

Patients who have family support will feel that the illness is a disaster and the family always accompanies it in the treatment of the disease, the family provides time for treatment and gives praise and attention to the patient which makes the patient feel needed and needed in the family that makes the patient feel necessary To carry out self-care for family support, it is also because the family understands and knows about leprosy to improve family support better, so that socialization is needed that is more effective and good for families and communities.

Patients who have self-acceptance have the ability to accept criticism can even take the wisdom and criticism. Individuals try to make corrections to themselves. Leprosy patients who have low selfacceptance tend to consider criticism in society as a rejection of themselves, but leprosy patients who have high self-acceptance consider criticism as constructive input, positive thinking and self-respect as it is that makes leprosy patients do self care so as not become disabled so that people can accept leprosy patients

This causes self-acceptance to be the most powerful factor affecting self care of leprosy patients. Selfacceptance is an internal factor that greatly affects leprosy patients in doing self care, self care is a daily activity based on individual awareness of self acceptance without conditions

\section{CONCLUSION}

The degree of disability with self care of leprosy patients in Daha Husada Kediri Hospital with the results of p 0.641 Pearson correlation 0.044 so that the degree of disability has no significant relationship with self care. Stigma with self care of leprosy patients at Daha Husada Kediri Hospital with the results of $\mathrm{p} 0.311$ Pearson correlation -0.095 so that the stigma has no significant relationship with self care. Family support with self care of leprosy patients at Daha Husada Kediri Hospital with the results of $p$ 0,000 Pearson correlation 0.483 so that family support has a strong relationship with self care. Self-acceptance with self care of leprosy patients at Daha Husada Kediri Hospital with the results of p 0,000 Pearson correlation 0.584 so that self-acceptance has a strong relationship with self care.

\section{REFERENCES}

Chaplin, J.P.(2008), Kamus lengkap Psikologi, Jakarta: PT. Rajagrafindo Persada

Dhelya Widasmara, (2018). Penyakit Kusta Sebuah Perspektif Klinis. Cetakan Pertama, Universitas Brawijaya, Malang

Friedman. (2010) Buku Ajar Keperawatan Keluarga Riset, Teori, dan Praktek, Edisi kelima, Fakultas Kedokteran Universitas Indonesia, Jakarta

Kemenkes RI, (2012). Pedoman Nasional Program Pengendalian Penyakit Kusta. Jakarta: Kemenkes RI.

Kemenkes RI, (2014). Pedoman Nasional Program Pengendalian Penyakit Kusta. Jakarta Direktorat Jendral Pengendalian Penyakit Dan Penyehatan Lingkungan 
Kemenkes RI, (2017), Pusat Data dan Informasi. InfoDatin. Jakarta: Kemenkes RI.

Kurnianingtyas, R. (2009). Penerimaan Diri pada Wanita Bekerja Usia Dewasa Dini ditinjau dari status Pernikahan (doctoral disertation, UniversitasMuhamadyah Surakarta).

Lucka, E.E. (2010), Understanding The Stigma Of Leprosy. Sout Sudan Medical Journal, 3(3) 45-48

Nursalam, (2013). Metodologi Penelitian Ilmu Keperawatan Edisi 3. Jakarta: Salemba Medika.

Phelan.J.C., Link, B.G., \& Dovidio, J.F. (2008). Stigma and Prejudice: One Animal or Two?. Sosial Science \& Medicine, 67(3), 358-367

RS, Kusta Kediri. (2018). Profil RS Kusta Kediri, Kediri : RS. Kusta Kediri

Soedarjadmi, S, Istiarti T, \& Widagdo, L (2009) Faktor-Faktor yang melatrbelakangi Persepsi Penderita terhadap Stigma Penyakit Kusta Journal Promosi Kesehatan Indonesia

Sulidah, S. (2016), Hubungan Pengetahuan dan Sikap Masyarakat Terkait Kusta Terhadap Perlakuan Diskriminasi pada Pasien Kusta. Medika Respati, 11(3)

Siokal, Patnawati, Sudarman, (2017). Falsafah Dan Teori Dalam Keperawatan. Jakarta: Trans Info Media.

Susanto, Tantut, (2013). Perawatan Klien Di Komunitas. Jakarta: Trans Infor Media.

Wong.M.L, (2014). Designing Programmes To Adress Stigma In Leprosy: Issue And Chalengger. Asia Pasific Disablity Rehabilitation Journal, Vol. 15 No 2.

World Healt Organization. (2000). World Healt Statistics. World Healt Organization 